\title{
У Pandemia-aika hoivakotiasukkaiden läheisten näkökulmasta: huolta, turhautumista ja uusia avauksia
}

\author{
Jenny Paananen ${ }^{1}$, Johanna Rannikko ${ }^{1}$, Maija Harju ${ }^{2}$, Jari Pirhonen ${ }^{2}$ \\ ${ }^{1}$ Hoitotieteen laitos, Lääketieteellinen tiedekunta, Turun yliopisto

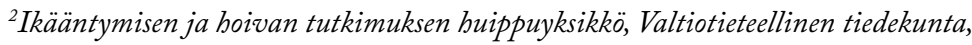 \\ Helsingin yliopisto
}

\begin{abstract}
Tutkimuksessa tarkastellaan hoivakotiasukkaiden läheisten kokemuksia koronapandemiasta. Laadullisen tutkimuksen aineistona on 41 läheisten kanssa tehtyä teemahaastattelua (794 sivua litteroituna) ja metodina aineistolähtöinen sisällönanalyysi. Tulosten mukaan vierailukiellot ja etäisyyden pitäminen ovat heikentäneet läheisten hyvinvointia sekä suhdetta asukkaaseen ja hoitotahoon. Läheiset olivat huolissaan asukkaan voinnista ja hoidosta ja kokivat tilanteen vuoksi ahdistusta, surua ja voimakasta stressiä. Moni kertoi asukkaan terveyden tai toimintakyvyn heikentyneen pandemian aikana huomattavasti, ja voinnissa tapahtuneiden muutosten uskottiin johtuvan aktiviteettien ja sosiaalisten kontaktien puutteesta. Läheiset kärsivät myös siitä, etteivät he saaneet turvavälivaatimuksen vuoksi osoittaa hellyyttä tai osallistua asukkaan hoitamiseen, kuten syöttämiseen. Vierailemista ilman yhteisiä aktiviteetteja ei aina koettu mielekkääksi, ja osa oli turhautunut epäreiluiksi kokemiensa käytäntöjen vuoksi. Läheisillä oli kuitenkin myös hyvin myönteisiä kokemuksia hoivakotien joustavasta toiminnasta ja poikkeusoloja varten kehitetyistä uusista yhteistyön muodoista. Tulokset korostavatkin tarvetta kehittää turvallisia tapoja, joilla läheiset voivat osallistua hoivakotiasukkaiden elämään ja hoivaan myös poikkeuksellisina aikoina.
\end{abstract}

\section{Johdanto}

Keväällä 2020 covid-19-pandemia levisi nopeasti ympäri maailman ja johti erilaisiin sosiaalisen kanssakäymisen rajoituksiin (Linka ym. 2020; Studdert \& Hall 2020). Koska covid-19-taudin tiedettiin olevan erityisen vaarallinen iäkkäille (D'Adamo ym. 2020), hoivakoteihin asetettiin Suomessakin ensin vierai- lukielto (STM 2020), ja kesästä 2020 alkaen läheisten ja asukkaiden kanssakäymistä alettiin säädellä erilaisin rajoituksin tartuntariskin minimoimiseksi (vierailujen järjestämisestä ks. esim. THL 2020). Ohjeistusten tulkinnassa oli kuitenkin huomattavaa vaihtelua, ja vaikka Valvira (2020) huomautti, ettei läheisten tapaamisia tai asukkaan poistumista hoivakodista voida kategorisesti kieltää, noin 1 prosentissa 
hoivakodeista vierailukielto oli edelleen voimassa vuoden 2020 lopussa (Saramaa \& Kervinen 2021). Keväällä 2021, tätä kirjoitettaessa, hoivakotien tilanne ei ole vielä normalisoitunut.

Suomen hoivakodeissa asuu noin 50000 ikääntynyttä asukasta (THL 2021a), eli läheiset mukaan lukien vierailurajoitukset vaikuttavat varsin merkittävään joukkoon ihmisiä. Oikeus nauttia yksityis- ja perhe-elämän kunnioitusta on perusoikeus (Euroopan ihmisoikeussopimus 63/1999). Vierailurajoituksia koskevien ohjeistusten (EOAK 3232/2020; EOAK 5463/2020; THL 2020; 2021b; Valvira 2020) avulla on pyritty turvaamaan iäkkäiden ihmisten perusoikeuksien toteutumista (täydellisten vierailukieltojen sijaan) ja ennaltaehkäisemään pandemiasta aiheutuvia haittoja, mutta tilanne on joka tapauksessa rajoittanut hoivakotien asukkaiden mahdollisuuksia pitää yhteyttä läheisiinsä ja käyttää hoivakodin ulkopuolisia palveluita (Blain ym. 2020; Cohen ym. 2020; Topo 2020). THL:n (Kehusmaa ym. 2021) tutkimuksen mukaan kotihoidon ja hoivakotien asukkaat ovat olleet eristäytyneisyydestään huolimatta melko tyytyväisiä elämänlaatuunsa mutta tunteneet itsensä yksinäisemmiksi kuin aikaisemmin. Viidennes vastaajista ilmoitti, etteivät he olleet voineet ulkoilla lainkaan sosiaalisten rajoitusten alkamisen jälkeen.

On arvioitu, että pandemiaan liittyvä sosiaalinen eristäytyneisyys ja arkisen aktiivisuuden väheneminen ovat vaikuttaneet kielteisesti heikoimmassa asemassa olevien iäkkäiden ihmisten hyvinvointiin (Cohen ym. 2020; E1 Haj ym. 2020; Jolanki 2020; Topo 2020). Yhtenä ratkaisuna eristäytyneisyyden kielteisten vaikutusten ehkäisemiseen on ehdotettu uusien viestintäteknologioiden käytön lisäämistä hoivakodeissa (Banskota ym. 2020; Edelman ym. 2020; Noone 2020), mutta erityisesti muistisairaille asiakkaille mahdollisuudet sosiaalisen elämän ylläpitämiseen esimerkiksi videopuheluiden välityksellä voivat olla hyvin rajallisia tai olemattomia (Jolanki 2020; Pirhonen ym. 2020). Suurin osa hoivakotien asukkaista sairastaa muistisairauksia (Helvik ym. 2015; Nuutinen ym. 2020), mikä todennäköisesti vaikuttaa heidän kykyynsä ymmärtää tilannetta ja pandemiaan liittyviä rajoituksia. Pandemia-aikana hoivakotien asukkaiden vointi on heikentynyt, ja masennus, ahdistus ja harhaisuus ovat lisääntyneet erityisesti muistisairautta sairastavilla (Brooks ym. 2020; El Haj ym. 2020; Lima ym. 2020; Pirhonen ym. 2020). Suomessa hoivakodissa asutaan elämän viimeiset vuodet, keskimäärin kaksi vuotta (Topo 2020), ja eristys tässä vaiheessa elämää on voinut tuntua toivottomalta (vrt. Lima ym. 2020).

Sosiaali- ja terveydenhuollon toimijoiden tulisi toimia yhteistyössä asiakkaan läheisten kanssa kokonaisvaltaisen hoidon toteuttamiseksi (Laki ikääntyneen väestön toimintakyvyn tukemisesta sekä iäkkäiden sosiaali- ja terveyspalveluista 980/2012; WHO 2017). Vuorovaikutus läheisten kanssa helpottaa hoivakodin asukkaan tarpeiden tunnistamista (Kiljunen ym. 2017). Ennen pandemiaa läheiset ovat voineet osallistua asukkaan hoitoon tai kuntouttaviin toimiin (Hertzberg \& Ekman 2000; Looman ym. 2002; Ward-Griffin ym. 2003), mutta he ovat olleet korvaamattomia ennen kaikkea asukkaiden sosiaalisten suhteiden ylläpitämisessä ja yksilöllisyyden tukemisessa (Alice Lau ym. 2008; Pirhonen \& Pietilä 2015). Aiemman tutkimuksen mukaan läheiset ovat kokeneet hoitoon osallistumisen merkityksellisenä (Palmer 2012; Duggleby ym. 2013; Holmgren ym. 2013). Osallistuessaan hoivakodin arkeen he ovat kokeneet voivansa samalla valvoa hoidon laatua (Vohra ym. 2004; Natan 2009) erityisesti tilanteissa, joissa asukas ei itse ole kykenevä keskustelemaan omasta hyvinvoinnistaan (Haesler ym. 2006).

Pandemia-aika on ollut vaikeaa myös läheisille. Iäkkäät puolisot eivät ole voineet tavata toisiaan, pahimmillaan edes kuoleman lähestyessä (Topo 2020). Vaikka viestintäteknologioiden avulla on voitu parantaa tiedonkulkua hoivakodista läheisille, huoli asukkaiden tilanteesta ja epätietoisuus rajoitusten kestosta ovat heikentäneet läheisten hyvinvointia (Pirhonen ym. 2020; Paananen ym. 2021). Tiedämme kuiten- 
kin edelleen hyvin vähän pandemian vaikutuksista hoivakotien asukkaiden ja heidän läheistensä elämään Suomessa. Tämän tutkimuksen tarkoituksena on avata tilannetta nimenomaan läheisten näkökulmasta.

\section{Aineisto ja menetelmät}

\section{Tutkimuksen eettisyys}

Tutkimus toteutettiin hankkeiden Alongside Dementia (Jenny Paananen, Turun yliopisto, rahoitus: Suomen Akatemia) ja Kuoleman ja kukkaron välissä: muistisairaan vanhuksen elämän loppuvaibeen boidon haasteet (Jari Pirhonen, Helsingin yliopisto, rahoitus: Koneen Säätiö) yhteistyönä. Hankkeilla on Turun ja Helsingin yliopistojen eettisten toimikuntien puoltavat lausunnot sekäTurun alueen Hyvinvointitoimialan tutkimuslupa. Tutkimuseettistä ohjeistusta (TENK 2019) noudatettiin tarkasti. Kasvokkaiseen haastattelututkimukseen osallistuneet saivat etukäteen kirjallista ja suullista tietoa tutkimushankkeista, osallistumisen vapaaehtoisuudesta sekä aineistonkäsittelyn periaatteista. Heillä oli myös mahdollisuus esittää tutkijoille kysymyksiä ennen osallistumista. Puhelinhaastatteluissa kaikki informaatio annettiin suullisesti. Matkustamisen välttämiseksi kasvokkain toteutettavia haastatteluja tarjottiin vain niille, jotka asuivat lähellä tutkijoita. Kasvokkain tehdyissä haastatteluissa osallistujat allekirjoittivat suostumuslomakkeen, ja puhelinhaastatteluissa suullinen suostumus nauhoitettiin. Kasvokkain tehdyissä haastatteluissa huolehdittiin turvaväleistä ja käytettiin kasvomaskeja. Hoivakodit eivät luovuttaneet tutkijoille henkilötietoja läheisistä tai asukkaista. Osallistujille on annettu pseudonyymit, ja esitetyistä haastatteluotteista on poistettu tunnistetiedot.

\section{Haastatteluaineisto ja sen hankkiminen}

Tutkimuksen aineistona on 41 äänitteeksi tallennettua temaattista haastattelua, jotka on to- teutettu vuonna 2020 huhtikuun ja joulukuun välisenä aikana. Haastateltavat ovat hoivakotien asukkaiden läheisiä eri puolilta Suomea, ja heidät on tavoitettu tutkimuskutsulla usean eri hoivakodin ja Muistiyhdistyksen kautta. Hoivakodeille toimitettiin kirjallinen tutkimuskutsu, jonka avulla tai jota mukaillen he ovat voineet välittää tiedon kutsusta asukkaiden läheisille.

On todennäköistä, että tutkimukseen ovat osallistuneet hoivakodeissa aktiivisimmin vierailevat läheiset. Tämä tulee huomioida tulosten tulkinnassa, sillä aiemman tutkimuksen perusteella aktiiviset läheiset voivat olla keskimääräistä enemmän huolissaan asukkaiden voinnista ja suhtautua siten myös keskimääräistä kriittisemmin heidän saamaansa hoitoon (Vohra ym. 2004; Natan 2009). Toisaalta taas voidaan olettaa, että hoivakodit ovat välttäneet välittämästä tutkimuskutsua sellaisille läheisille, joiden kanssa heillä on ollut konflikteja tai huomattavaa erimielisyyttä, jolloin osallistujajoukon ei voi ajatella edustavan kaikkein kriittisimpiä ääniä.

Haastatteluista 23 tehtiin puhelimitse ja 18 kasvokkain. Osallistujista valtaosa oli naisia (35/41), mikä tukee aiempien tutkimusten havaintoa naisten korostuneesta roolista asukkaiden elämässä (Keefe \& Fancey 2000; Holmgren ym.2013). Osallistujien ikä vaihteli 40 ja 83 vuoden välillä. Puheena olevista hoivakotiasukkaista 34/41 sairasti läheisen kertoman mukaan muistisairautta, ja he asuivat 23:ssa eri hoivakodissa.

Kaikki neljä kirjoittajaa osallistuivat haastattelujen tekemiseen. Kolmella kirjoittajista oli kokemusta hoitotyöstä, mutta tämän ei katsottu olevan este vaan ennemminkin etu tulosten pohtimisen kannalta. Muutama haastateltavista tunsi haastattelijan entuudestaan, mutta haastattelut toteutettiin samalla rungolla siten, ettei mahdollisia aiempia tietoja huomioitu. Haastattelut kestivät 11 minuutista 107 minuuttiin, ja litteroituna aineistoa on 794 sivua (fontti Calibri 12). Koska haastattelun teemoina oli myös muita omaisena olemiseen ja hoivakodin henkilökunnan kanssa kommunikoi- 
miseen liittyviä aiheita, aineistosta erotettiin tätä tutkimusta varten pandemiaa koskevat osuudet, jolloin aineistoa jäi 206 sivua.

\section{Analyysimenetelmänä sisällönanalyysi}

Tutkimusmenetelmänä oli aineistolähtöinen sisällönanalyysi, jossa aineistoa analysoidaan sen sisällöstä käsin koodaten keskeisiä teemoja, eikä koodausta ohjaa esimerkiksi tietynlainen teoria tai ennalta luotu malli (Elo \& Kyngäs 2008; Neuendorf ym. 2017). Sisällön koodaamisessa hyödynnettiin NVivo12-analysointityökalua, jonka avulla tutkija voi luokitella aineistoa erilaisiin noodeihin eli kategorioihin ja järjestellä niitä hierarkkisesti. Työkalun etuna on, että ohjelma laskee automaattisesti esiintymien määrän ja luo linkit poimituista katkelmista alkuperäiseen tiedostoon, jolloin sanotun laajempaan kontekstiin on vaivatonta tutustua uudelleen.

Ensimmäisessä vaiheessa kirjoittajista $\mathrm{Paa}-$ nanen ja Pirhonen koodasivat pandemiaan liittyviä seikkoja vapaasti lähilukemisen ohessa. Seuraavaksi Paananen ryhmitteli sisältöä kuvaavat koodit teemoittain ja luokitteli ne erilaisiin ylä- ja alakategorioihin. Sitten hän kävi aineiston läpi vielä uudelleen etsien lisää esiintymiä analyysissa syntyneisiin luokkiin. Lopuksi kaikki kirjoittajat pohtivat luokkia ja niiden nimityksiä yhdessä. Analyysin lopputuloksena läheisten kokemukset pandemian vaikutuksista jaettiin kolmeen pääteemaan: 1) vaikutukset läheisten vointiin, 2) vaikutukset läheisten ja asukkaiden suhteeseen ja 3) vaikutukset läheisten ja hoitotahon suhteeseen. Vaikutukset luokiteltiin myönteisesti ja kielteisesti koettuihin. Sisällönanalyysin teemat ja koodit esiintymismäärineen on koottu taulukkoon 1. Tutkimuksen ja raportoinnin tukena käytettiin laadullisen tutkimuksen tarpeisiin kehitettyä COREQ-tarkistuslistaa (Tong ym. 2007) soveltuvin osin.

\section{Tulokset}

Kuten taulukosta 1 näkyy, läheisten näkökulmasta pandemian vaikutukset koettiin pääosin kielteisinä (33 myönteistä ja 341 kielteistä esiintymää). Suurin osa läheisistä koki etäisyyden pitämisen heikentäneen sekä omaa että hoivakodissa asuvan omaisensa vointia, ja moni oli etääntynyt sekä asukkaasta että hoivakodin henkilökunnasta. Osalla oli kuitenkin myös myönteisiä kokemuksia hoivakotien tekemistä vierailujärjestelyistä, ja he olivat kiitollisia hoitokodilta saamastaan tuesta. Seuraavaksi käsitellään läheisten kertomuksia yksityiskohtaisemmin teema-alue kerrallaan.

Läheisten vointi pandemian aikana: huolta, lepoa ja syyllisyyttä

Analyysin perusteella läheisten vointiin vaikutti ennen kaikkea huoli omaistensa voinnista. Huolta aiheutti sosiaalisten kontaktien ja aktiviteettien puuttuminen sekä yksinäisyyden vaikutukset asukkaan elämän laatuun. Yksin huoneisiinsa suljetut asukkaat vaikuttivat masentuneilta, ja osa oli kertonut läheiselle eristykseen liittyvistä tunteistaan. Ella kertoi isänsä yksinäisyyden kokemuksesta seuraavasti:

\section{Isälläkin on ekoja kertoja ku bän on miettiny elämän merkitystä, et onko minun elämällä mitään merkitystä ku täällä vaan istun ja ai- noo virike on televisio. (Ella, asukkaan tytär)}

Myös Marjan äiti ikävöi perhettään ja puhui elämän merkityksen katoamisesta:

Hän sanoo, että hän kuolee tähän tylsyyteen ja hän kuolee tähän eristykseen. Että ettekö te nyt ymmärrä, että tällä elämällä ei oo paljo mitään arvoa, kun kaikki se mikä bänelle jotain merkitsee eli hänen perheenjäsentensä näkeminen, lasten, lastenlasten ja lastenlastenlasten näkeminen on niin tärkeetä. (Marja, asukkaan tytär) 
Taulukko 1. Sisällönanalyysin teemat ja koodit.

\begin{tabular}{|c|c|c|}
\hline Teema & $\begin{array}{l}\text { Etäisyyden pitämisen vaikutukset hoivakotiasukkaiden } \\
\text { läheisten näkökulmasta }\end{array}$ & $\mathbf{N}$ \\
\hline \multirow{15}{*}{ Läheisen vointi } & Myönteisiksi koetut vaikutukset & 13 \\
\hline & Helpotuksen tunne & 11 \\
\hline & Enemmän aikaa levolle ja itsestä huolehtimiselle & 2 \\
\hline & Kielteisiksi koetut vaikutukset & 192 \\
\hline & Huoli & 92 \\
\hline & Huoli asukkaan psyykkisestä voinnista & 31 \\
\hline & Huoli asukkaan fyysisen kunnon heikkenemisestä & 25 \\
\hline & Huoli asukkaan muistisairauden nopeasta etenemisestä & 12 \\
\hline & Huoli asukkaan hoidosta & 24 \\
\hline & Ahdistus, turhautuminen ja suru & 72 \\
\hline & Syyllisyys poissa olemisesta & 10 \\
\hline & Syyllisyys yhteyden pitämisestä & 8 \\
\hline & Tunteiden jatkuvasta käsittelystä johtuva kuormitus & 5 \\
\hline & Yksinäisyys (asukkaiden puolisot) & 4 \\
\hline & Fyysisen kunnon heikkeneminen & 1 \\
\hline \multirow{7}{*}{$\begin{array}{l}\text { Läheisen ja asukkaan } \\
\text { suhde }\end{array}$} & Myönteisiksi koetut vaikutukset & 1 \\
\hline & Entistä läheisempi suhde & 1 \\
\hline & Kielteisiksi koetut vaikutukset & 45 \\
\hline & Yhteisten aktiviteettien väheneminen tai puuttuminen & 16 \\
\hline & Läheinen tuntee asukkaan etäisemmäksi & 14 \\
\hline & Asukas ei ymmärrä etäisyyden pitämisen syitä & 12 \\
\hline & Asukas ottaa etäisyyttä läheisiin & 3 \\
\hline \multirow{7}{*}{$\begin{array}{l}\text { Läheisen ja hoivakodin } \\
\text { henkilökunnan välinen } \\
\text { suhde }\end{array}$} & Myönteisiksi koetut vaikutukset & 19 \\
\hline & Uudet yhteistyömuodot & 19 \\
\hline & Kielteisiksi koetut vaikutukset & 104 \\
\hline & Läheinen kokee kommunikaation puutteelliseksi & 32 \\
\hline & Läheinen kokee hoivan laadun heikentyneen & 30 \\
\hline & Läheinen kokee hoivakodin käytännöt epäreiluiksi & 23 \\
\hline & Läheinen kokee henkilöstön ylikuormittuneeksi & 19 \\
\hline \multirow{2}{*}{ Yhteensä } & Myönteisiksi koetut vaikutukset & 33 \\
\hline & Kielteisiksi koetut vaikutukset & 341 \\
\hline
\end{tabular}

Suunniteltujen retkien, juhlien ja kotivierailujen peruuntuminen oli myös läheisille kova paikka. Myös se, etteivät läheiset voineet enää huolehtia omaisestaan itse esimerkiksi syöttämällä tai järjestämällä hierontaa tai muita palveluita, ahdisti ja suretti heitä. Puhelimitse saadut uutiset omaisen voinnin heikkenemisestä huolestuttivat ja saattoivat aiheuttaa pelon ja avuttomuuden tunteita. Päivistä tuntui pahalta kuulla äidin syömättömyydestä, sillä hän koki, että olisi voinut pelastaa tilanteen, jos olisi saanut mennä paikalle:

Niin sillon muutamaan viikkoon me ei käyty ollenkaan, mut sit saatiin koko ajan vähän ikävii uutisii. Et aina ku me soitettiin, joka päivä, ni aina et ei ole äiti syönyt ja ei ole mitään. Sit tuli semmonen olo vähän et no perkele, et kuolee... Ja mä tiedän kuitenki et mä saan mun äitini syömään ku mä käytän sii- 
ben aikaa ja paneudun siiben. (Päivi, asukkaan tytär)

Monet läheisistä puhkesivat kyyneliin haastattelun aikana. Taina oli huolissaan sekä omasta että äitinsä jaksamisesta, ja hän oli alkanut pitää puhelintaan mukana siltä varalta, että hoivakodista soitetaan huonoista uutisista:

En tiiä miten tässä kuule jaksaa. Ja miten äiti jaksaa. Sitähän me tässä pelätään kaikkein eniten, että me ei päästä äidin lähellä olemaan näitä sen viimeisiä päiviä. Jos sanon, siis kuolemanpelkohan mulla on koko aika äidistä. Ja sit se että mul on pubelin sillä lailla, $m m m$. (Taina, asukkaan tytär)

Myös Marja pelkäsi, että hänen hoivakodissa asuva äitinsä menettää eristyksessä elämänhalunsa. Marjalle ajatus siitä, ettei hän voisi olla mukana viimeisinä hetkinä, oli musertava:

No kyl mä aattelen että se on kuolemaksi äidille, et ei hän jaksa tätä. Et se semmonen, jotenki sisäinen periks antaminen elämälle, joka on joka tapauksessa tietysti tuossa iässä olemassa, kun vaivoja on ja muita, niin se on totta, mutta se että myöskin tämä, eristys ja sitte se buoli että jos äiti sairastuu niin me ei saataisi olla sitte häntä saattelemassa niin, se aibeuttaa mulle iban kaubean suurta surua ja tuskaa. (Marja, asukkaan tytär)

Osalle ensimmäinen tapaaminen sulun jälkeen oli järkytys. Meri muisteli, että hänen äitinsä oli kävellyt ennen sulkua, ja sulun jälkeen vastassa oli ollut puhumaton, jäykistynyt vuodepotilas. Heidin isä puolestaan oli asunut kesän 2020 alussa vielä itsenäisesti ja urheillut päivittäin. Eksymisten vuoksi isä päätyi ensin väliaikaiseen hoitoyksikköön, jossa liikkumista rajoitettiin. Heidi oli huolissaan isän saamasta hoidosta, erityisesti lääkityksestä:
Et hän, et hän oli ihan tota noin ni semmonen apaattinen ja lääkitty. (--) Mä viel kysyin sielt et minkälainen lääkitys hänel on ku bän on iban toimintakyky ja pubekyky men$n y . \mathrm{Ni}$ he, et se jobtuu varmaan kyl tost aktiviteettien puutteesta ja tota noin ni, tän sairauden etenemisestä. Ni mä sanoin et, et ei se kyl voi jobtuu. Et ei hän nyt ihan muutamas viikos voi mennä pyöräileväst ibmisest, semmoseen kuntoon et hän ei pysty pubumaan eikä eikä tota noin ni, kävelemään. (Heidi, asukkaan tytär)

Vaikka voinnin heikkeneminen kuuluu esimerkiksi muistisairauteen, haastateltavia äkilliset muutokset askarruttivat ja ahdistivat. Osa yhdisti muutokset sosiaalisten tilanteiden puuttumiseen ja osa, kuten Heidi yllä olevassa katkelmassa, hoitoon liittyviin ratkaisuihin. Läheisten ja hoivakotien välistä suhdetta pandemia-aikana käsitellään artikkelissa jäljempänä.

Kaikilla läheisillä ei kuitenkaan ollut huolta asukkaiden voinnista, vaan osa ajatteli, ettei pandemia juurikaan vaikuttanut siihen. Osa taas koki, että etäisyyden pitäminen oli läheisille paljon stressaavampi kokemus kuin asukkaille. Tällaisia näkemyksiä perusteltiin muistisairauden luonteella: kun asukas ei kykene ymmärtämään tilannetta, hän ei kanna siitä huolta.

En mä usko et muistisairaat kärsii siit ollenkaa itte nii mahdottomasti. Tää on nyt ihan oma ajatus, kun beil on se oma maailmansa. Osa on mielikuvitusmaailmaa, he elelee jossai, kattoo ikkunast ulos ja näkee mitä sattuu, niinku äitiki. Et he elää siin omas maailmas. Nii ei se paljon heilauta, se et ei niit, vieraita ibmisiä siin niin kaubeesti käy. (Esko, asukkaan poika)

Muutama läheinen oli löytänyt pandemia-ajasta myös hyviä puolia. Esimerkiksi muutama läheinen, joka oli aiemmin käynyt lähes päivittäin hoivakodissa, kertoi levänneensä ja huolehtineensa omasta hyvinvoinnistaan aiempaa 
paremmin vierailukiellon aikana. Laila oli nukkunut ja remontoinut kotiaan. Marista tuntui kuin olisi lomalla. Ilman poikkeusoloja vierailematta jättäminen olisi ollut monelle mahdoton ajatus, kuten Marjukka kertoo:

\section{Ni mä jotenkin olin, helpottunu, jos mä ihan suoraan tunnustan, siiben et mun ei enää tar- vinnu repiä sillon maaliskuun jälkeen. Pari viikkoo mä olin aivan niinku tosi tyytyväinen, et mun ei tarvinnu enää repii itteäni äidin luo, koska mä en pystyny olee käymättä sielläkään. (Marjukka, muistisairaan tytär)}

Tilanne aiheutti läheisille myös ristiriitaisia syyllisyyden tuntemuksia. Etäisyyden pitäminen saattoi tuntua hylkäämiseltä. Läheisen tietoisuus siitä, ettei asukas todennäköisesti kykene muistisairauden vuoksi ymmärtämään poissaolon syytä, sai ajattelemaan muita tulkintoja, joita asukas voisi tilanteelle antaa. Marjukka kertoikin, että helpotuksen tunnetta seurasi paha olo:

Mä baluisin käydä, mä en halua niinku hänt bylätä, tällee. Tuli semmonen niinku bylkäämisen tunne et nyt, nyt mä oon nyt jättäny sit oman onnen nojaan, vaik mä tiesin et kaikki on tosi byvin. (Marjukka, muistisairaan tytär)

Toisaalta syyllisyyden tunteita seurasi myös hoivakodissa vierailemisesta, sillä silloin läheinen tunsi ottavansa riskin koronaviruksen leviämisestä ja rikkovansa näin yhteiskunnan asettamia pelisääntöjä. Läheiset joutuivat siis tasapainottelemaan kahden vastakkaisen vaatimuksen välillä ollakseen "kunnollisia kansalaisia”: yhtäl̈ltä heidän oli pidettävä huolta lähimmäisistään ja toisaalta tehtävä osuutensa viruksen leviämisen torjunnassa.

Sit mä menin, mut tosi buonol omatunnol ja vähän niinku anteeks pyydellen, voiks tänne tulla. Mä en oikeen tiedä, tuntu et hoitajat- kaan ei ehkä samal taval tervehdi enää niin paljon, et mä en tiiä onks ne silleen, subtautuuko nibkeesti ku me käydään siellä kuitenki isän kanssa. Sit yks kertaki ku mä menin sinne ni oli ihan semmonen, siis hirvee semmonen häpeä et voinks mä nyt olla täs. (Päivi, asukkaan tytär)

Tulosten perusteella on selvää, että pandemiaaika on ollut hoivakotien asukkaiden läheisille varsin raskasta aikaa. Seuraavaksi tarkastellaan vielä erikseen pandemian vaikutuksia läheisten ja asukkaiden sekä läheisten ja hoivakotien henkilökunnan välisiin suhteisiin.

Läheisten ja asukkaiden välinen suhde: ikävää ja etääntymistä

Vain yksi haastatelluista läheisistä kertoi pandemian lähentäneen välejä asukkaaseen. Kaikista haastatteluista ei käy ilmi, että suhde asukkaaseen olisi muuttunut, mutta moni kertoi kielteisistä kokemuksista, joiden voi katsoa vaikuttaneen suhteeseen heikentävästi. Osa haastateltavista puolestaan kuvasi suoraan suhteen muuttumista etäisemmäksi. Risto esimerkiksi totesi, että nyt on tullu semmonen tuntuma että niinkun tota... menee päiviä ettei muistakaan et hän [puoliso] on. Marjukka koki, että koskettaminen oli erilaista kertakäyttökäsine kädessä kuin paljaalla iholla. Kaikki eivät saaneet koskettaa asukkaita lainkaan, ja se koettiin etäännyttävänä. Esimerkiksi Taina kuvasi tuntemuksiaan seuraavasti:

Onhan se nyt etäisempi. Et ei oo, ei ole niin läheinen kun saisin näbdä ja koskee äitiä tossa. On ihan, siis järkyttävää ja ällöttävää ja inhottavaa. Mä inhoon tätä koko koronaa. (Taina, asukkaan tytär)

Kertomuksista heijastuu myös, että hoivakodin asukkaille erityisjärjestelyt voivat tuntua epämiellyttäviltä, mikäli asukas pelkää olevansa muille taakka. Esimerkiksi Taina kertoi, ettei 
hänen äitinsä halunnut hänen järjestävän ulkotapaamisia, koska tämä ei halunnut hänen näkevän vaivaa vuokseen. Elinan äiti alkoi samasta syystä vetäytyä videopuheluista:

Hän huolehtii vaan siitä että jaksaako se hoi-
taja pidellä sitä padia. Kato ku aina on huo-
lehtinu toisten hyvinvoinnista. Et jaksaako
hoitaja pidellä padia. Ei siit tuu mitään siitä
keskustelusta. (Elina, asukkaan tytär)

Muistisairaus oli tuonut omat vaikeutensa suhteen ylläpitoon. Jotkut asukkaista olivat aluksi pelänneet maskeja, ja osa asukkaista ei ollut tunnistanut läheistään maskin takaa. Koronatilanteen ymmärtäminen yleisellä tasolla oli monelle asukkaalle vaikeaa, ja he saattoivat antaa etäisyyden pidolle erilaisia merkityksiä. Anneli esimerkiksi kertoi, että tämän äiti oli havainnut, että vierailut olivat vähentyneet, mutta koska hän ei kyennyt muistamaan, mistä syystä, hän oli arvellut sen johtuvan jostakin, mitä hän on itse tehnyt tai sanonut. Suhteen lujittaminen tällaisessa tilanteessa oli vaikeaa.

Ja sitten koitan sanoa että kun minä en saa tulla sinne, et kun on tämä kielto, et siellä ei vierailut ole sallittua ja näin. Ja hän luul, että hän on loukannu minua. Pyytää anteeksi, että kun minä en käy. Hän on kokenu sen aika lailla ikävänä tietenkin. (Anneli, asukkaan tytär)

Kuten jo edellä kuvattiin, läheisen näkökulmasta myös osallistuminen asukkaan hoivaan voi olla hyvin merkityksellistä. Esimerkiksi yhteiset kahvihetket ja hiusten kampaaminen olivat monelle olleet olennainen osa vierailun sisältöä. Etenkin niiden asukkaiden kohdalla, joiden muistisairaus oli edennyt pitkälle, läheiset kokivat turvavälien pitämisen vierailujen aikana turhauttavaksi. Heistä tuntui, ettei kumpikaan osapuoli hyötynyt tällaisista tapaamisista. Ritva pohti: jos mä menen sinne puoleks tunniks ja bän [puoliso] istuu silmät kiinni ja suu auki niin ei siin niinku semmosta kontaktii ei saa enää.
Tutkimuksen perusteella onkin olemassa riski, että pitkään jatkuessaan rajoitukset etäännyttävät läheiset asukkaista myös henkisesti. Virpi kertoi päästäneensä vähän irti asukkaasta vuoden aikana, ja Krista tunnusti: joka ilta mä rukoilen että äiti nukkuis pois. Muistisairaudet aiheuttavat tyypillisesti läheisille surua ja menetyksen tuntemuksia jo ennen sairastuneen kuolemaa (Alzheimer's Society 2017), ja haastatteluaineiston perusteella pandemia-aika on voinut nopeuttaa läheisten luopumisprosessia.

Läheisten ja hoivakotien välinen suhde: katkeruutta ja uutta yhteistyötä

Läheisten suhde hoivakoteihin oli haastattelujen perusteella koetuksella vuonna 2020. Etääntyminen hoivakodin arjesta aiheutti läheisille huolta, sillä he eivät voineet enää tarkkailla asukkaiden vointia ja hoitoa eivätkä vaikuttaa niihin omalla panoksellaan samalla tavalla kuin aiemmin. Hoivakotien viestintäosaaminen ja yhteydenpitoa varten laaditut ratkaisut näyttävät vaikuttaneen ratkaisevasti huolen määrään. Läheiset, jotka kokivat, että tieto kulki hyvin ja että hoivakoti oli pyrkinyt joustamaan ja aktiivisesti ratkaisemaan koronatilanteen tuomia haasteita, ilmaisivat luottamusta hoitotahoa kohtaan. Esimerkiksi hoivakodista oma-aloitteisesti lähetetyt kuulumiset ja kuvaviestit oli koettu myönteisinä. Läheiset arvostivat myös sitä, että hoitajat olivat auttaneet heitä yhteydenpidossa asukkaan kanssa.

Ja meillä on siitä syntynyt nyt birveen positiivinen kuva, että soittaa sinne koska tahansa ja juttelee kenen tahansa hoitajan kans, niin ne on aina byvin kartalla niistä, siis ne tuntee ne asukkaansa byvin. Se on ollu omiaan herättään sellaista luottamusta. Ja sitten että kun niitä videopuheluitakin on soitettu niin, kyllä niillä on ollu resurssi siihen että ne on esimerkiks istunu äitin vieressä ja pitäny sitä puhelinta. (Sirpa, asukkaan tytär) 
Pari haastatelluista kertoi tehneensä itse hoivakodille aloitteen ulkotapaamisten aloittamisesta, ja ehdotuksen toteutuminen tuntui heistä hyvältä. Yksi läheisistä kertoi, että hoivakodin taholta oli järjestetty hänelle jopa kuljetus vierailulle, ettei hänen tarvinnut käyttää julkista liikennettä.

No sillonkin johtaja haki sitte, yhden hoitajan kans minut kotoonta ja vei. Ja ymmärräkkö, se hoitaja, se teki lumityötkin mulle vielä. Ennen ku ne päästivät autollekaan. Voi että sentään. Et kyl, ei mul oo mitään semmosta negatiivista sanomista näistä et tota, et kaubean hyvin ne on, kaikki toi. (Laila, asukkaan puoliso)

Kaikilla haastatteluun osallistuneilla ei kuitenkaan ollut kokemusta tiivistyneestä yhteistyöstä, ja moni ilmaisi pettymystä ja suuttumusta hoivakotien tekemiä ratkaisuja kohtaan. Vaatimus säilyttää fyysinen etäisyys oli vaikea hyväksyä, jos läheisestä tuntui, että vaatimukset koskivat vain läheisiä eivätkä esimerkiksi hoivakodin henkilöstöä tai kuljetuspalvelujen työntekijöitä.

Siis semmoinen mustasukkaisuus, joka mua on itteeni alkanu ärsyttää ihan suunnattomasti, sekä ihan äidin kohdalla, että vieraat ibmiset saa olla niin paljon tekemisissä ja olla lähellä. Niin se on jotenkin birveen raskasta, et miksen minä. Ja sitten, kun mä oon ite hoitajataustainen ja nyt sitten en oo enää hoitotyössä, et mä ebkä kahen viikon välein käyn kaupassa, niin mä oon niin likainen että mä en voi millään suojauksilla tavata äitiäni tai mennä lähelle. (Eila, asukkaan tytär)

Tiukkojen rajoitusten lisäksi turhautumista läheisille aiheutti, jos ratkaisuja joutui odottamaan ja kyselemään. Huomionarvoista on, että kritiikki voitiin kohdistaa nimenomaan siihen, etteivät hoivakodit soveltaneet ketterämmin olemassa olevia ohjeita, eikä niinkään siihen, millaisia valtakunnalliset ohjeistukset kulloinkin olivat.
Kun me pyydettiin äitiä ulos sillo jo alkuvaiheessa että ulkona voitas tavata. Niin, ne vartos vaan koko aika jotakin. Hallitukselta tai mistä ne nyt odottikin jotaki sitte. Määräyksiä että. Miksei ne omaa järkee voinu käyttää. (Krista, asukkaan tytär)

Konfliktitilanteitakin oli syntynyt, mutta usein näiden seurauksena tilanne oli läheisen näkökulmasta parantunut. Esimerkiksi Venla oli hakenut tuekseen lääkärin mielipiteen, kun häntä oli kielletty syöttämästä miestään, ja hoivakoti oli joustanut. Pekka taas kertoi vastustaneensa tapaamisajan rajoitusta seuraavasti:

Se [tapaamisaika] oli se 15 minuuttii. Jopa oli yks semmonen hoitaja, että sil oli kello tällä tavalla kädessä, ja ku se sekuntiviisari näytti, et se 15 minuuttia on nyt jämpti ni vaik ois lusikka ollu menossa, kun, mä sanoin heti siinä kun Ullal ei ollu sit enää toisella kertaa maskia mut mul oli maski, ni mä syötin hänelle marjoja. Lusikal annoin. Ja sanoin, että soittakaa poliisit, jos haluatte, mut minä haluan antaa vaimolleni nämä marjat. Ja juu ei, anna vaan. (Pekka, asukkaan puoliso)

Kuten Pekan kertomuksesta voi päätellä, rajoitukset ja niiden noudattaminen olivat stressaavia sekä henkilöstölle että läheisille. Haastatteluista ilmeni myös, että joillekin läheisille yhteyden ottaminen oli vaikeaa, koska he ajattelivat kuormittavansa hoitajia ja häiritsevänsä asukkaiden päivittäistä hoitoa. Jatkossa olisikin tärkeää, että hoivakodeissa tunnistettaisiin paremmin läheisten huoli ja että siihen vastattaisiin rakentavalla tavalla. Esimerkiksi aktiivinen yhteydenpito läheisten kanssa sekä uudenlaiset keinot, joilla läheinen voi osallistua asukkaan elämään, näyttivät parantavan niin läheisten suhdetta hoivakotiin kuin luottamusta hoidon laatuun. 


\section{Pohdinta}

Tutkimuksessa tarkasteltiin hoivakotiasukkaiden läheisten kokemuksia covid-19-pandemian ajasta teemahaastattelujen ja aineistolähtöisen sisällönanalyysin avulla. Tulokset osoittavat, että julkinen keskustelu hoivakotiasukkaiden eristämisen riskeistä on ollut aiheellista (esim. Jolanki 2020; Jylhä 2020; Topo 2020). Vierailukielto ja vierailuun liittyvät rajoitukset olivat läheisille monella tapaa raskaita ja vaikuttivat myös läheisten ja asukkaiden sekä läheisten ja hoivakotien välisiin suhteisiin. Erityisesti läheisiä painoi huoli omaisensa voinnista ja hoidosta. Moni kertoi omaisen kunnon heikenneen rajoitusten aikana huomattavasti, ja osa pelkäsi menettävänsä viimeiset mahdollisuudet viettää aikaa yhdessä. Samankaltaisia havaintoja läheisten huolista ovat tehneet myös Pirhonen ja kumppanit (2020) hoivakotiasukkaiden läheisten kirjoittamista sähköpostikirjeistä. Hoivakotiasukkaiden terveyden ja voinnin on niin ikään todettu heikentyneen pandemia-aikana useissa tutkimuksissa (esim. Brooks ym. 2020; El Haj ym. 2020; Lima ym. 2020).

Läheisiä huoletti myös asukkaiden yksinäisyys, ja lisäksi erityisesti asukkaiden puolisot kokivat yksinäisyyttä itsekin. Myös kvantitatiivisissa tutkimuksissa on todettu yksinäisyyden lisääntyneen iäkkäillä covid-19-pandemian aikana, mikä on erityisesti mielenterveyden näkökulmasta huolestuttavaa (esim. Heidinger \& Richter 2020; Kehusmaa ym. 2021). Toisaalta on havaittu, että kotona asuvilla iäkkäillä on hyviä selviytymiskeinoja tilapäisen yksinäisyyden kestämiseksi (Fuller \& Huseth-Zosel 2021). Hoivakotiasukkaille oman sosiaalisen hyvinvoinnin ylläpitäminen on kuitenkin vaikeaa, ja siksi läheisten ja hoitavan tahon tulisi huolehtia siitä heidän kanssaan. Asukkaiden pitäminen yksin omissa huoneissaan ei ole ainoastaan läheisten murheenaihe vaan todellinen asukkaiden elämänlaatua ja itsemääräämisoikeutta heikentävä asia (ks. myös Street \& Burge 2012; Topo 2020).
Tässä tutkimuksessa haastatellut läheiset kertoivat myös kokeneensa ahdistusta, pelkoa ja surua, jotka ovat niin ikään riskejä psyykkiselle hyvinvoinnille. Tulosten perusteella näyttää siltä, että etäisyyden pito ja sen seuraukset ovat voineet nopeuttaa läheisillä muistisairauteen liittyvää luopumisprosessia (Alzheimer's Society 2017) - jotkut haastatelluista näyttivät etääntyneen asukkaasta myös tunnetasolla. Etäisyyden vaikutukset läheisten terveyteen eivät olleet kuitenkaan yksinomaan kielteisiä, vaan joillekin pandemia-aika oli tuonut kaivattua aikaa levolle ja itsestä huolehtimiselle. Tämänkaltaisia myönteisiä vaikutuksia voisi todennäköisesti edistää parantamalla läheisten luottamusta asukkaan hoitoa kohtaan.

Aiemman tutkimuksen perusteella hoivaan osallistumisen tiedetään olevan muistisairaiden ihmisten läheisille erityisen tärkeää (Cohen ym. 2014), ja kosketuksen tiedetään vaikuttavan suotuisasti muistisairaan vointiin ja ymmärtämiseen (Bush 2001; Wu ym. 2017). Odotuksen mukaisesti haastatellut läheiset kokivat fyysisen etäisyyden vaatimuksen raskaaksi. Omaisia suretti, etteivät he voineet koskettaa asukasta tai osallistua tämän hoivaan esimerkiksi syöttämällä tai kampaamalla. Tapaamiset ilman yhteistä tekemistä tai mahdollisuutta hoivaan tuntuivat osan mielestä jopa turhilta, ja vierailujen voikin olettaa vähentyneen huomattavasti. Osa läheisistä oli myös turhautunut epäreiluiksi kokemiensa käytäntöjen vuoksi, mikä heijastui kielteisinä tuntemuksina hoivakoteja kohtaan.

\section{Tutkimuksen luotettavuus}

Vaikka aineisto oli riittävä laadulliseen tutkimukseen ja läheisten kokemuksia voidaan pitää luotettavina, tutkimuksella on tiettyjä rajoituksia. Ensinnäkin pandemian aiheuttamien rajoitusten takia tässä tutkimuksessa keskityttiin vain läheisten näkemyksiin, eli asukkaiden hyvinvointia koskevat käsitykset ovat välillisiä. Ennestään tiedetään, että monet tekijät saatta- 
vat vaikuttaa läheisten arvioihin muistisairauteen sairastuneiden henkilöiden hyvinvoinnista. Läheiset saattavat esimerkiksi vertailla hoivakotiasukkaan vointia hänen aikaisempaan toimintakykyynsä, kun taas sairastuneet itse vertaavat vointiaan ennemmin muiden samassa tilanteessa olevien vointiin (Smith ym. 2005). Myös läheisten omaan terveyteen ja elämänlaatuun liittyvät kokemukset voivat heijastua heidän tekemiinsä arvioihin (Arons ym. 2013). Toisaalta kaikki tässä tutkimuksessa mainitut hoivakotiasukkaat eivät olisi kyenneet mielekkäästi ilmaisemaan haastattelussa itseään edenneen muistisairautensa vuoksi, vaikka pandemia ei olisikaan rajoittanut tutkimustyötä hoivakodeissa. Jälkikäteen ajateltuna myös taustatietojen tarkempi selvittäminen olisi voinut olla hyödyllistä. Esimerkiksi arvio läheisten osallistumisesta hoitoon ennen pandemiaa ja sen aikana olisi saattanut tuottaa arvokasta lisätietoa, koska hoitoon osallistuminen on yhteydessä läheisten kokemaan stressiin ja käsityksiin hoidon laadusta (Friedemann ym. 1997; Tornatore \& Grant 2002).

\section{Johtopäätökset}

Kaiken kaikkiaan näyttää siltä, että ohjeistuksia on hoivakodeissa tulkittu paikoin liiankin tiukasti, jolloin terveyden suojelua varten tehdyt rajoitukset ovat heikentäneet asukkaiden ja heidän läheistensä hyvinvointia sekä läheisten luottamusta hoivakoteja kohtaan. Elämän laadun sijaan on korostunut elämän pituus, ja asukkaiden itsemääräämisoikeutta on loukattu monin tavoin (vrt. Amnesty International 2020; Jolanki 2020). Koska tilanne ei edelleenkään ole ohi, olisi tärkeää, että sosiaalisten rajoitusten haittavaikutuksista keskusteltaisiin avoimesti ja että resursseja suunnattaisiin haittavaikutusten minimoimiseen (vrt. Allen \& Ayalon 2021; Gallo \&Wilber 2021; Paananen ym. 2021).

Ensiarvoisen tärkeää olisi kehittää turvallisia tapoja, joilla läheiset voivat osallistua asuk- kaiden elämään mielekkäällä tavalla. Haastattelujen perusteella läheiset arvostavat pieniäkin eleitä hoivakodin taholta: viesti tai puhelu kuulumisista, kuvaviesti tai mahdollisuus koskettaa asukasta käsine kädessä voivat merkitä paljon. Jotkin poikkeuksellista aikaa varten kehitetyistä käytännöistä ovat niin onnistuneita, että niitä kannattaa jatkaa myös pandemian jälkeen.

Yhteistyön vahvistaminen läheisten kanssa olisi hyödyllistä myös asukkaille, koska se vähentää tutkitusti muistisairauteen liittyviä käytösoireita (Robison ym. 2007). Asukkaiden hyvinvoinnin kannalta olisi myös tärkeää, että tilanteissa, joissa fyysisen etäisyyden pitäminen läheisiin on välttämätöntä, sosiaalisia kontakteja kompensoitaisiin muilla tavoin. Esimerkiksi lisäämällä hoivakodin sisäisiä aktiviteetteja ja vuorovaikutusta asukkaiden välillä poikkeuksellisina aikoina olisi mahdollista ehkäistä tässäkin tutkimuksessa havaittuja kielteisiä vaikutuksia (ks. myös Fuller \& Huseth-Zosel 2021; Nelson \& Bergeman 2021; Whitehead \& Torossian 2021).

Koska läheisten luottamusta hoivaa kohtaan rakennetaan myös - tai ennen kaikkea - vuorovaikutuksen keinoin (ks. Looman ym. 2002; Heinrich ym. 2003; Alice Lau ym. 2008), hoivakotien hallintohenkilöstön olisi hyvä päivittää säännöllisesti hoivakodin viestintästrategiaa ja miettiä, kenelle, mistä asioista, missä kanavissa ja milloin tiedotetaan. Lisäksi läheisille tulisi tarjota riittävästi informaatiota siitä, milloin ja miten heidän on sopivaa ottaa yhteyttä ja kenen kanssa asukkaan asioista voi keskustella. Vähentämällä läheisten epätietoisuutta ja epävarmuutta voidaan vähentää myös heidän kokemaansa huolta.

\section{Yhteydenotto:}

Jenny Paananen, FT, tutkijatohtori

Hoitotieteen laitos

Lääketieteellinen tiedekunta

Turun yliopisto

jenny.paananen@utu.fi 


\section{Kirjallisuus}

Alice Lau WY, Lotus Shyu YI, Lin LC, Yang PS. Institutionalized elders with dementia: collaboration between family caregivers and nursing home staff in Taiwan. J Clin Nurs 2008;17:482-90. https://doi.org/10.1111/j.13652702.2007.01955.x.

Allen LD, Ayalon L. "It's pure panic": the portrayal of residential care in American newspapers during COVID-19. Gerontologist 2021;61:8697. https://doi.org/10.1093/geront/gnaa162.

Alzheimer's Society. Grief, loss, and bereavement. 2017. Internet: https://www.alzheimers.org.uk/ sites/default/files/pdf/factsheet_grief_loss_and_ bereavement.pdf (viitattu 2.3.2021).

Amnesty International. As if expendable. The UK Government's failure to protect older people in care homes during the COVID-19 pandemic. 2020. Internet: https://www.amnesty.org.uk/ files/2020-10/Care Homes Report.pdf (viitattu 27.4.2021).

Arons AM, Krabbe PF, Scholzel-Dorenbos CJ, Wilt GJ van der, Olde Rikkert MG. Quality of life in dementia: a study on proxy bias. BMC Med Res Methodol 2013;13:e110. https://doi.org/10.1186/1471-2288-13-110

Banskota S, Healy M, Goldberg EM. 15 smartphone apps for older adults to use while in isolation during the Covid-19 pandemic. West J Emerg Med 2020;21:514-25. https://doi.org/10.5811/westjem.2020.4.47372.

Blain H, Rolland Y, Schols JMGA, Cherubini A, Miot S, O'Neill D, ym. August 2020 Interim EuGMS guidance to prepare European Long-Term Care Facilities for COVID-19. Eur Geriatr Med 2020;11:899-913. https://doi.org/10.1007/s41999-020-00405-z.

Brooks SK, Webster RK, Smith LE, Woodland L, Wessely S, Greenberg N, ym. The psychological impact of quarantine and how to reduce it: rapid review of the evidence. Lancet 2020;395:912-20. https://doi.org/10.1016/S0140-6736(20)30460-8.

Bush E. The use of human touch to improve the well-being of older adults: a holistic nursing intervention.J Holist Nurs Off J Am Holist Nurses' Assoc 2001;19:256-70. https://doi.org/10.1177/089801010101900306.

Cohen G, Julieta Russo M, Campos JA, Allegri RF. COVID-19 epidemic in Argentina: Worsening of behavioral symptoms in elderly subjects with dementia living in the community. Front Psychiatry 2020;11:e866.

https://doi.org/10.3389/fpsyt.2020.00866.

Cohen LW, Zimmerman S, Reed D, Sloane PD, Beeber AS, Washington T,ym. Dementia in relation to family caregiver involvement and burden in long-term care. J Appl Gerontol Off J South Gerontol Soc 2014;33:522-40. https://doi.org/10.1177/0733464813505701.

D'Adamo H, Yoshikawa T, Ouslander JG. Coronavirus disease 2019 in geriatrics and long-term care: the ABCDs of COVID-19. J Am Geriatr Soc 2020;68:912-7. https://doi.org/10.1111/jgs.16445.

Duggleby W, Schroeder D, Nekolaichuk C. Hope and connection: the experience of family caregivers of persons with dementia living in a long term care facility. BMC Geriatr 2013;13:e112. https://doi.org/10.1186/1471-2318-13-112.

Edelman LS, McConnell ES, Kennerly SM, Alderden J, Horn SD, Yap TL. Mitigating the effects of a pandemic: facilitating improved nursing home care delivery through technology. JMIR Aging 2020;3:e20110.

https://doi.org/10.2196/20110.

El Haj M, Altintas E, Chapelet G, Kapogiannis D, Gallouj K. High depression and anxiety in people with Alzheimer's disease living in retirement homes during the covid- 19 crisis. Psychiatry Res 2020;291:e113294.

https://doi.org/10.1016/j.psychres.2020.113294.

Elo S, Kyngäs $H$. The qualitative content analysis process. J Adv Nurs 2008;62:107-15. https://doi.org/10.1111/j.13652648.2007.04569.x.

EOAK 3232/2020. Vanhuksiin kohdistuvat rajoitukset koronaepidemian aikana. Internet: https://www.oikeusasiamies.fi/r/fi/ratkaisut/-/ eoar/3232/2020 (viitattu 1.4.2021).

EOAK 5463/2020. Vanhusten tapaamisten ja liikkumisen toteuttaminen hoivayksiköissä koronapandemian aikana. Internet: https://www.oikeusasiamies.fi/r/fi/ratkaisut/-/eoar/5463/2020 (viitattu 9.4.2021).

Euroopan ihmisoikeussopimus 63/1999.

Friedemann M, Montgomery RJ, Maiberger B, Smith AA. Family involvement in the nursing home: family-oriented practices and staff-family relationships. Res Nurs Health 1997;20:527-37. 
https://doi.org/10.1002/(sici)1098-

240x(199712)20:6\%3C527::aid-

nur7\%3E3.0.co;2-o

Fuller HR, Huseth-Zosel A. Lessons in resilience: initial coping among older adults during the COVID-19 pandemic. Gerontologist 2021;61:114-25.

https://doi.org/10.1093/geront/gnaa170.

Gallo HB, Wilber KH. Transforming aging services: area agencies on aging and the COVID-19 response. Gerontologist 2021;61:152-8.

https://doi.org/10.1093/geront/gnaa213

Haesler E, Bauer M, Nay R. Factors associated with constructive staff-family relationships in the care of older adults in the institutional setting. JBI Libr Syst Rev 2006;4:1-72.

https://doi.org/10.11124/01938924-

200604090-00001.

Heidinger T, Richter L. The effect of COVID-19 on loneliness in the elderly: an empirical comparison of pre-and peri-pandemic loneliness in community-dwelling elderly. Front Psychol 2020;11:e585308.

https://doi.org/10.3389/fpsyg.2020.585308.

Heinrich M, Neufeld A, Harrison MJ. Seeking support: caregiver strategies for interacting with health personnel. Can J Nurs Res = Rev Can Rech En Sci Infirm 2003;35:38-56.

Helvik AS, Engedal K, Benth JŠ, Selbæk G. Prevalence and severity of dementia in nursing home residents. Dement Geriatr Cogn Disord 2015;40:166-77.

https://doi.org/10.1159/000433525

Hertzberg A, Ekman S. 'We, not them and us?' Views on the relationships and interactions between staff and relatives of older people permanently living in nursing homes. J Adv Nurs 2000;31:614-22.

https://doi.org/10.1046/j.1365-

2648.2000.01317.x.

Holmgren J, Emami A, Eriksson LE, Eriksson H. Being perceived as a "visitor" in the nursing staff's working arena - the involvement of relatives in daily caring activities in nursing homes in an urban community in Sweden. Scand J Caring Sci 2013;27:677-85.

https://doi.org/10.1111/j.1471-

6712.2012.01077.x

Jolanki O. Rajankäyntiä. Gerontologia 2020;34:71-3. Internet: https://journal.fi/gerontologia/article/ view/102739 (viitattu 1.4.2021).
Jylhä M. Ikä, korona ja tutkijan tehtävä. Blogikirjoitus. Gerontologian tutkimuskeskus. 2020. Internet: https://www.gerec.fi/ika-korona-ja-tutkijan-tehtava/ (viitattu 6.4.2021).

Keefe J, Fancey P. The care continues: responsibility for elderly relatives before and after admission to a long term care facility. Fam Relat 2000;49:23544.

https://doi.org/10.1111/ j.1741-3729.2000.00235.x.

Kehusmaa S, Siltanen S, Leppäaho S. Hyvinvointi korona-aikana - tuloksia vanhuspalvelujen asiakastyytyväisyyskyselystä. Tutkimuksesta tiiviisti 10/2021. Helsinki: Terveyden ja hyvinvoinnin laitos, 2021.

Kiljunen O, Välimäki T, Kankkunen P, Partanen P. Competence for older people nursing in care and nursing homes: an integrative review. Int J Older People Nurs 2017;12.

https://doi.org/10.1111/opn.12146

Laki ikääntyneen väestön toimintakyvyn tukemisesta sekä iäkkäiden sosiaali- ja terveyspalveluista 980/2012.

Lima CKT, Carvalho PM de M, Lima I de AAS, Nunes JVA de O, Saraiva JS, de Souza RI, ym. The emotional impact of Coronavirus 2019$\mathrm{nCoV}$ (new Coronavirus disease). Psychiatry Res 2020;287:e112915. https://doi.org/10.1016/j.psychres.2020.112915

Linka K, Peirlinck M, Sahli Costabal F, Kuhl E. Outbreak dynamics of COVID-19 in Europe and the effect of travel restrictions. Comput Methods Biomech Biomed Engin 2020;23:710-7. https://doi.org/10.1080/10255842.2020.1759560

Looman WJ, Noelker LS, Schur D, Whitlatch CJ, Ejaz FK. Impact of family members on nurse assistants: what helps, what hurts. Am J Alzheimers Dis Other Demen 2002;17:350-6. https://doi.org/10.1177/153331750201700606

Natan MB Coordinating the roles of nursing home staff and families of elderly nursing home residents. J Nurs Care Qual 2009;24:332-9. https://doi.org/10.1097/NCQ.0b013e3181a8b257.

Nelson NA, Bergeman CS. Daily stress processes in a pandemic: the effects of worry, age, and affect. Gerontologist 2021;61:196-204. https://doi.org/10.1093/geront/gnaa187

Neuendorf K, Skalski P, Cajigas, Julie; Allen J. The content analysis guidebook. Los Angeles: SAGE, 2017. 
Noone C. Video calls for reducing social isolation and loneliness in older people: a rapid review. Cochrane Database Syst Rev 2020;5:1-40. https://doi.org/10.1002/14651858.CD013632

Nuutinen M, Leskelä RL, Torkki P, Suojalehto E, Tirronen A, Komssi V. Developing and validating models for predicting nursing home admission using only RAI-HC instrument data. Informatics Heal Soc Care 2020;45:292-308. https://doi.org/10.1080/17538157.2019.1656212

Paananen J, Rannikko J, Harju M, Pirhonen J. The impact of Covid-19-related distancing on the well-being of nursing home residents and their family members: a qualitative study. International Journal of Nursing Studies Advances 2021;3:e100031. https://doi.org/10.1016/j.ijnsa.2021.100031

Palmer JL. Caregivers' desired patterns of communication with nursing home staff - just TALKKK! J Gerontol Nurs 2012;38:47-54. https://doi.org/10.3928/00989134-20120207-03

Pirhonen J, Blomqvist K, Harju M, Laakkonen R, Lemivaara M. Etäläheiset - hoivakotien koronaeristys asukkaiden läheisten kokemana. Gerontologia 2020;34:244-58. https://doi.org/https:// doi.org/10.23989/gerontologia.95669

Pirhonen J, Pietilä I. Patient, resident, or person: recognition and the continuity of self in longterm care for older people. J Aging Stud 2015;35:95-103. https://doi.org/10.1016/j.jaging.2015.05.004

Robison J, Curry L, Gruman C, Porter M, Henderson CR Jr, Pillemer K. Partners in caregiving in a special care environment: cooperative communication between staff and families on dementia units. Gerontologist 2007;47:504-15. https://doi.org/10.1093/geront/47.4.504

Saramaa M, Kervinen R. Asiakkaiden itsemääräämisoikeus ja rajoitustoimenpiteet ympärivuorokautisissa vanhustenhuollon yksiköissä Covid-19-pandemian aikana marras-joulukuussa 2020. Valvira, 2021. Internet:

https://www.valvira.fi/documents/14444/326610/Asiakkaiden_itsemaaraamisoikeus_covid_pandemian_aikana_21012021. pdf/c2cf57c4-1dc0-49da-5fe6-ecac83ccc4a9? $\mathrm{t}=1611214059968$ (viitattu 1.4.2021).

Smith SC, Murray J, Banerjee S, Foley B, Cook JC, Lamping DL, ym. What constitutes health-related quality of life in dementia? Development of a conceptual framework for people with dementia and their carers. Int J Geriatr Psychiatry 2005;20:889-95.

https://doi.org/10.1002/gps.1374

STM. Hallitus on todennut yhteistoiminnassa tasavallan presidentin kanssa Suomen olevan poikkeusoloissa koronavirustilanteen vuoksi. Sosiaali- ja terveysministeriö. Tiedote 140/2020. Internet: https://stm.fi/-/10616/hallitus-totesi-suomen-olevan-poikkeusoloissa-koronavirustilanteen-vuoksi (viitattu 1.4.2021).

Street D, Burge SW. Residential context, social relationships, and subjective well-being in assisted living. Res Aging 2012;34:365-94. https://doi.org/10.1177/0164027511423928

Studdert DM, Hall MA. Disease control, civil liberties, and mass testing - calibrating restrictions during the Covid-19 pandemic. N Engl J Med 2020;383:102-4. https://doi.org/10.1056/NEJMp2007637

THL. Koronavirustartuntojen torjunta pitkäaikaishoidon ja -hoivan toimintayksiköissä. Terveyden ja hyvinvoinnin laitos, 2020. Internet: https:// thl.fi/fi/web/infektiotaudit-ja-rokotukset/taudit-ja-torjunta/taudit-ja-taudinaiheuttajat-a-o/ koronavirus-covid-19/koronavirustartuntojen-torjunta-pitkaaikaishoidon-ja-hoivan-toimintayksikoissa (viitattu 1.4.2021).

THL. Sosiaali- ja terveysalan tilastollinen vuosikirja 2020. Suomen virallinen tilasto (SVT): Sosiaaliturva 2020. Vantaa: Terveyden ja hyvinvoinnin laitos, 2021a.

THL. Vierailut pitkäaikaishoidon ja -hoivan toimintayksiköissä koronavirusaikana. Terveyden ja hyvinvoinnin laitos, 2021b. Internet: https:// thl.fi/fi/web/infektiotaudit-ja-rokotukset/ taudit-ja-torjunta/taudit-ja-taudinaiheuttajat-a-o/koronavirus-covid-19/koronavirustartuntojen-torjunta-pitkaaikaishoidon-ja-hoivan-toimintayksikoissa/vierailut-pitkaaikaishoidon-ja-hoivan-toimintayksikoissa_koronavirusaikana (viitattu 9.4.2021).

Tong A, Sainsbury P, Craig J. Consolidated criteria for reporting qualitative research (COREQ): a 32-item checklist for interviews and focus groups. Int J Qual Heal Care 2007;19(6):349-57. https://doi.org/10.1093/intqhe/mzm042

Topo P. Koronarajoitukset suojasivat taudilta, mutta monen iäkkään ja vammaisen henkilön hyvinvointi heikkeni. Teoksessa: COVID 19-epide- 
mian eettinen arviointi. ETENE-julkaisuja 47. Helsinki: Valtakunnallinen sosiaali- ja terveysalan eettinen neuvottelukunta ETENE, Helsinki, 2020:48-51.

Tornatore JB, Grant LA. Burden among family caregivers of persons with Alzheimer's disease in nursing homes. Gerontologist 2002;42:497-506. https://doi.org/10.1093/geront/42.4.497

TENK. Ihmiseen kohdistuvan tutkimuksen eettiset periaatteet ja ihmistieteiden eettinen ennakkoarviointi Suomessa. Tutkimuseettisen neuvottelukunnan ohje 2019. Tutkimuseettisen neuvottelukunnan julkaisuja 3/2019.

Valvira. Perusoikeuksien toteutuminen ja tartuntojen ehkäisy sosiaalihuollossa. Ohjauskirje kunnille ja palveluntuottajille. Sosiaali- ja terveysalan lupaja valvontavirasto, 2020. Internet: https://www.valvira.fi/documents/14444/326610/Perusoikeudet_ohje.pdf/a67c563a-6f1b-eb56-c14b42d09f6819b1? $t=1599048634739$ (viitattu 1.4.2021).

Vohra JU, Brazil K, Hanna S, Abelson J. Family perceptions of end-of-life care in long-term care facilities. J Palliat Care 2004;20:297-302.
Ward-Griffin C, Bol N, Hay K, Dashnay I. Relationships between families and registered nurses in long-term-care facilities: a critical analysis. Can J Nurs Res 2003;35:150-74.

WHO. Global action plan on the public health response to dementia 2017-2025. World Health Organization, 2017. Internet: https://apps.who.int/iris/bitstream/handle/1 0665/259615/9789241513487-eng.pdf;jsessionid=1099A3ED88E696C94F03CDB0E526495F?sequence=1 (viitattu 26.2.2021).

Whitehead BR, Torossian E. Older adults' experience of the COVID-19 pandemic: a mixed-methods analysis of stresses and joys. Gerontologist 2021;61:36-47. https://doi.org/10.1093/geront/gnaa126.

Wu J, Wang Y, Wang Z. The effectiveness of massage and touch on behavioural and psychological symptoms of dementia: a quantitative systematic review and meta-analysis. J Adv Nurs 2017;73:2283-95. https://doi.org/10.1111/jan.13311 